\title{
Dinamika dan Problematika Politik Hukum Lembaga Penyelesai Sengketa Hasil Pemilihan Kepala Daerah di Indonesia
}

\author{
Nasrullah, Tanto Lailam
}

DATA NASKAH

Masuk: 5 Januari 2017

Diterima: 1 Mei 2017

Terbit: 1 Juni 2017

KORESPONDEN PENULIS:

Fakultas Hukum Universitas

Muhammadiyah Yogyakarta Jalan Lingkar Selatan, Tamantirto,

Kasihan, Bantul, Yogyakarta, 55183. E-mail: udanasrul2010@gmail.com tanto_tatanegara@yahoo.com

\section{ABSTRACT}

The success of free and fair local elections is not only measured by the voting process, but also determined on how the settlement of the disputes follows it. In connection with that, the institutional dispute settlement of local elections in Indonesia has experienced ups and downs that have not been interminable. The issuance of the Act Number 10 of 2016 which mandates the establishment of special judicial body for settlement of regional head election disputes still leaves a 'homework' of the shape or design of that special judicial institution, its authorities and procedural law that must be established ahead of national simultaneous elections in 2027. This paper is the result of a normative research with statute, analytical, and case approaches regarding the background of the existence of special judicial body which is needed to be established to resolve regional head election disputes in Indonesia as an antithesis on the weaknesses and problems of institutional settlement of regional head election disputes that been there for years, namely: Supreme Court and the Constitutional Court. In order to provide an overview as well as an alternative institutional model of special court for regional head election disputes settlement to be formed onward.

Keywords: Regional Head Election Disputes, Constitutional Court, Supreme Court, a Special Judicial Body

\section{ABSTRAK}

Sukses pilkada tidak hanya diukur dari tahapan pelaksanaannya, namun juga penyelesaian sengketa yang mengiringinya. Berkaitan dengan hal tersebut, lembaga penyelesai sengketa pilkada di Indonesia mengalami pasang surut yang tiada akhirnya. Dengan disahkannya Undang-undang No.10 tahun 2016 yang mengamanahkan pembentukan Badan Pengadilan Khusus untuk menyelesaikan sengketa hasil, masih meninggalkan permasalahan terkait desainnya, kewenangannya, dan hukum acara yang 


\section{MEDIA
HUKUM}

harus dibentuk menjelang Pilkada Serentak Tahun 2027. Penelitian ini merupakan penelitian hukum normatif dengan pendekatan perundang-undangan, analisis, dan pendekatan kasus yang bertujuan untuk mengetahui latar belakang gagasan pembentukan Badan Pengadilan Khusus Pilkada untuk menyelesaikan sengketa pemilihan kepala daerah di Indonesia sebagai antitesis dari kelemahan dan masalah-masalah dalam penyelesaian sengketa pemilihan kepala daerah yang telah berlangsung selama bertahun-tahun, yaitu: Mahkamah Agung dan Mahkamah Konstitusi. Hal ini untuk memberikan pandangan terbaik sebagai alternatif lembaga peradilan khusus penyelesaian sengketa pemilihan kepala daerah kedepannya.

Kata Kunci: Sengketa Pemilihan Kepala Daerah, Mahkamah Konstitusi, Mahkamah Agung, Badan Pengadilan Khusus.

\section{PENDAHULUAN}

Dalam sebuah negara demokrasi, pemilihan umum (pemilu) dianggap sebagai lambang sekaligus tolok ukur dari demokrasi itu sendiri. Pemilu merupakan conditio sine quanon dianutnya prinsip demokrasi dalam kehidupan berbangsa dan bernegara. Prinsip dasar kehidupan kenegaraan yang demokratis adalah setiap warga negara adalah berdaulat dan berhak ikut aktif dalam proses politik (Bisariyadi, dkk., 2012: 536), yang secara konkrit terejewantahkan dalam pemilu/ pilkada yang jujur dan adil (free and fair elections). Kedaulatan rakyat merupakan prinsip yang sangat mendasar dan dipandang sebagai moralitas konstitusi yang dalam pemilu diwujudkan dalam bentuk penghargaan dan penilaian suara pemilih yang tidak boleh didistorsi oleh kekuasaan partai politik untuk mengubah pilihan rakyat menjadi pilihan pengurus partai politik (Janedjri M.Gaffar, 2012: 29), dan tidak boleh dipakai sebagai sarana legitimasi kekuasaan sebagaimana terjadi dalam tiga dekade pemerintahan Orde Baru. Untuk memulihkan pemilu sebagai sarana perwujudan kedaulatan rakyat, Amandemen Ketiga UUD 1945 telah memasukkan ketentuan mengenai pemilu di dalam Pasal 22E UUD 1945 yang dielaborasi lagi dalam Putusan Mahkamah Konstitusi (MK) Nomor 3/PUU-VII/2009 (Janedjri M.Gaffar, 2012: 29).

Keberhasilan penyelenggaraan pemilu nasional tahun 1999 telah menjadi inspirasi untuk penataan demokrasi lokal dengan memaknai ketentuan Pasal 18 ayat (4) UUD 1945 yang berbunyi "Gubernur, Bupati, dan Walikota masingmasing sebagai kepala pemerintah daerah provinsi, kabupaten, dan kota dipilih secara demokratis" berupa pemilihan kepala daerah secara langsung melalui pembentukan Undang-undang No.32 Tahun 2004 tentang Pemerintahan Daerah, namun baru dapat dilaksanakan pada tahun 2005. Semangat dilaksanakannya pilkada langsung adalah koreksi terhadap sistem demokrasi tidak langsung (perwakilan) di era sebelumnya, dimana Kepala Daerah dan Wakil Kepala Daerah dipilih oleh DPRD. Dalam kacamata politik, perubahan ini merupakan perubahan konsep sistem pemerintahan di tangkat lokal dari 'sistem parlementarian' menjadi 'sistem presidensialisme' (Sigit Pamungkas, 2012: 61), dan merupakan pilihan yang sangat tepat dalam mengelola masa transisi Indonesia dari era otoritarian ke era demokratisasi yang sesungguhnya.

Untuk menjamin terwujudnya pemilihan kepala daerah secara langsung yang benar-benar sesuai dengan kaidah demokrasi, pelaksanaannya harus dilakukan dengan sistem yang mendasarkan pada prinsif free and fair melalui sistem yang baik dan integratif, antara lain: (1) tersedianya kerangka hukum materiil maupun formil yang berlaku, bersifat mengikat dan menjadi pedoman bagi penyelenggara, kontestan (pasangan calon), dan pemilih dalam menunaikan peran dan fungsi masing-masing, (2) terselenggaranya seluruh kegiatan atau tahapan yang terkait langsung dengan pelaksanaan pemilihan kepala daerah yang mendasarkan pada ketentuan perundang-undangan, (3) terintegrasinya proses penegakan hukum (electoral law enforcement) terhadap aturan-aturan pemilihan kepala daerah tersebut sesuai dengan tahapannya pada masing-masing tingkatan, baik yang menyangkut persoalan administratif, pidana, etika, dan juga perselisihan hasil. Sukses pilkada tidak hanya diukur dari tahapan perencanaan dan pelaksanaannya, namun juga penyelesaian sengketa yang mengiringinya. Dalam kaitan itulah pranata pengadilan yang ada sekarang memiliki keterbatasan dan belum memadai untuk mewujudkan keadilan pilkada. Terdapat loopholes (lubang) dalam mekanisme electoral dispute resolution (EDR) negara ini. Akibatnya, keadilan sesungguhnya belum didapatkan oleh mereka yang terlibat dan dirugikan dalam kontestasi pilkada (Refly Harun, 


\section{6: 339).}

Berkaitan dengan electoral law enforcement, khususnya terkait penyelesaian sengketa pilkada telah mengalami pasang surut, diawali dari kewenangan Mahkamah Agung (Pengadilan Tinggi) yang berwenang menyelesaikan sengketa pilkada, kemudian beralih ke Mahkamah Konstitusi, sampai dengan munculnya politik hukum pembentukan Badan Peradilan Khusus untuk menyelesaikan sengketa pilkada berdasarkan Undang-undang Nomor 8 Tahun 2015 tentang Penetapan Peraturan Pemerintah Pengganti Undang-Undang Nomor 1 Tahun 2014 tentang Pemilihan Gubernur, Bupati, dan Walikota Menjadi Undang-Undang. Dinamika pasang surut kelembagaan penyelesai sengketa pilkada ini tentu diakibatkan oleh problematika yang mengiringinya, baik ketidakadilan dan ketidakpastian hukum dalam penyelesaian sengketa pilkada sampai problem penafsiran konstitusi terhadap kewenangan konstitusional. Hingga saat ini harus mencari desain kelembagaan "badan peradilan khusus" pilkada yang belum jelas statusnya.

\section{METODE PENELITIAN}

\section{A. Tipe dan Pendekatan Penelitian}

Penelitian hukum merupakan penelitian yang diterapkan atau diberlakukan khusus pada ilmu hukum, yang membantu pengembangan ilmu hukum dalam mengungkap suatu kebenaran hukum. Penelitian ini mengenai dinamika dan problematika lembaga penyelesai sengketa pilkada yang selalu mengalami pasang surut dan ketidakpastian. Penelitian yang dipilih adalah penelitian doktrinal, adalah penelitian hukum yang meletakkan hukum sebagai sebuah bangunan sistem norma, sistem norma yang dimaksud adalah mengenai asas-asas, norma, kaidah dari peraturan perundangundangan, putusan pengadilan, perjanjian serta doktrin (ajaran) (Johny Ibrahim, 2005: 300). Penelitian hukum doktrinal dalam hal ini digunakan beberapa pendekatan, meliputi: (1) pendekatan perundang-undangan (statute approach), pendekatan perundang-undangan adalah dilakukan dengan cara menelaah peraturan perundang-undangan yang berkaitan dengan masalah hukum yang dikaji; (2) pendekatan analitis (analytical approach), bertujuan untuk mengkaji implementasi istilah-istilah hukum dalam berbagai undangundang ataupun putusan pengadilan; (4) pendekatan kasus (case approach), pendekatan ini untuk mempelajari normanorma atau kaidah hukum yang dilakukan dalam praktik hukum, dalam hal ini adalah pratik hukum penyelesaian sengketa pilkada yang dilakukan oleh peradilan sebelumnya (Johny Ibrahim, 2005: 300).

\section{B. Pengumpulan Data}

Teknik pengumpulan data dilakukan dengan penelitian kepustakaan (library research), yang bertujuan untuk menelaah bahan hukum primer, bahan hukum sekunder, dan bahan hukum tersier.

\section{Analisis Data}

Analisis data dalam penelitian ini menggunakan deskriptif kualitatif, peneliti dalam menganalisis berkeinginan untuk memberikan gambaran atau pemaparan atas objek penelitian sebagaimana hasil penelitian yang dilakukan (Mukti Fajar dan Yulianto Achmad, 2010:183). Analisa secara deskriptif kualitatif dilakukan dengan memperlakukan obyek berdasarkan kategori tertentu, misalnya pendekatan perundang-undangan memfokuskan pada analisis isi normatif dalam berbagai undang-undang, kategori tersebut bertujuan untuk menyeleksi data yang berkaitan dengan penelitian, kemudian diklasifikasikan secara yuridis dan sistematis. Penyusunan secara sistematis dimaksudkan untuk memberikan gambaran secara komprehensif hasil penelitian.

\section{HASIL PENELITIAN DAN ANALISIS}

\section{A. Pemilihan Kepala Daerah Langsung}

Pasal 18 ayat (4) UUD 1945 yang menyebutkan bahwa "Gubernur, Bupati, dan Walikota masing-masing sebagai kepala pemerintah daerah provinsi, kabupaten, dan kota dipilih secara demokratis", tidak mengatur secara limitatif apakah kepala daerah dipilih secara langsung oleh rakyat atau dipilih oleh DPRD. Paling tidak ada dua prinsip utama yang terkandung dalam rumusan "kepala daerah dipilih secara demokratis", yaitu: pertama; kepala daerah harus "dipilih" melalui proses pemilihan dan tidak dimungkinkan untuk langsung diangkat, kedua; pemilihan dilakukan "secara demokratis". Makna demokratis disini dapat dipilih langsung oleh rakyat dan dapat pula dipilih oleh DPRD yang anggota-anggotanya juga merupakan hasil pemilihan umum yang demokratis (Hamdan Zoelva, 2013: 380-381). 


\section{MEDIA
HUKUM}

Hasil akhir tafsir konstitusi oleh pembentuk undangundang terhadap Pasal 18 ayat (4) yang mengandung ketentuan "dipilih secara demokratis" adalah pemilihan langsung oleh rakyat (Pilkada). Hal ini semakin jelas ketika Undang-undang No.32 tahun 2004 tentang Pemerintahan Daerah diajukan oleh pemerintah dan diperdebatkan di DPR, tidak ada perdebatan yang mendalam lagi tentang apakah kepala daerah itu dipilih langsung oleh rakyat atau dipilih oleh DPRD. Hal ini, paling tidak disebabkan oleh dua hal, yaitu: telah disepakatinya dalam UUD 1945 bahwa Presiden dan Wakil Presiden dipilih secara langsung oleh rakyat, dan dari berbagai penyerapan aspirasi masyarakat di seluruh Indonesia, baik yang dilakukan oleh Tim Departemen Dalam Negeri maupun DPR, diperoleh aspirasi dominan dari masyarakat menghendaki kepala daerah itu dipilih secara langsung oleh rakyat. Hanya, yang menjadi perdebatan adalah bagaimana mekanisme pemilihan langsung ini dilakukan di setiap daerah apakah disamakan atau bisa berbeda-beda di masing-masing daerah disesuaikan dengan kondisi dan kekhususan masing-masing daerah. Rumusan akhir Undang-undang No.32 tahun 2004 tentang Pemerintahan Daerah, menujukkan dengan jelas bahwa mekanisme pemilihan ini lebih banyak diseragamkan dan hanya mengenai cara kampanye dan lain-lain yang bersifat sangat teknis diserahkan kepada daerah melalui KPUD masingmasing (Hamdan Zoelva, 2013: 380-381).

Pilkada merupakan salah satu terobosan politik yang signifikan dalam mewujudkan demokratisasi di tingkat lokal. Artinya, penyelenggaraan pemerintahan yang demokratis tercermin dalam 'recruitment' kepala pemerintahan (Zainal Arifin Hoesein, 2010: 21). Pemilu/ Pilkada merupakan wujud nyata demokrasi prosedural, meskipun demokrasi tidak sama dengan pemilu/ pilkada, namun merupakan salah satu aspek demokrasi yang sangat penting yang juga harus diselenggarakan secara demokratis (Nanik Prasetyoningsih, 2014 242). Sebagus apapun sebuah negara yang ditata secara demokratis, tidak akan dianggap benar-benar demokratis manakala pemimpin-pemimpinnya tidak dipilih secara bebas oleh rakyatnya sendiri. Bahkan, tak sedikit teoretisi demokrasi yang mengatakan bahwa pada dasarnya semua politik itu lokal, dan demokrasi di tingkat nasional akan tumbuh dan berkembang secara baik bila didukung oleh mantapnya nilai- nilai demokrasi lokal. Pilkada adalah bagian dari proses penguatan dan pendalaman demokrasi (deepening democracy) serta upaya mewujudkan tata pemerintahan yang efektif di tingkat lokal. Selain itu, pelaksanaan Pilkada pada dasarnya juga merupakan tindak lanjut realisasi prinsip-prinsip demokrasi yang meliputi jaminan atas prinsip-prinsip kebebasan individu dan persamaan khususnya dalam hak politik (Siti Zuhro, 2012: 30-31).

Beberapa pertimbangan penting penyelenggaraan Pilkada langsung adalah sebagai berikut: Pertama, Pilkada merupakan jawaban atas tuntutan aspirasi rakyat karena Presiden dan Wakil Presiden, DPR, DPD, bahkan Kepala Desa selama ini telah dilakukan secara langsung. Kedua, Pilkada merupakan perwujudan amanat Pasal 18 ayat (4) UUD 1945. Ketiga, Pilkada dipandang sebagai sarana pembelajaran demokrasi (politik) bagi rakyat (civics education). Keempat, Pilkada dipandang sebagai sarana untuk memperkuat otonomi daerah. Keberhasilan otonomi daerah salah satunya ditentukan oleh pemimpin lokal. Semakin baik pemimpin lokal yang dihasilkan melalui Pilkada, maka komitmen pemimpin lokal untuk meningkatkan masyarakat yang menjadi tujuan otonomi daerah dapat diwujudkan. Kelima, Pilkada merupakan sarana penting bagi proses kaderisasi kepemimpinan nasional. Saat ini, landasan penyelenggaraan pilkada adalah UU No. 1 Tahun 2015 tentang Pengesahan Peraturan Pemerintah Pengganti Undang-Undang (Perpu) Nomor 1 Tahun 2014 tentang Pemilihan Gubernur, Bupati dan Walikota yang telah diubah dengan UU No. 8 Tahun 2015, dan telah dirubah kembali dengan lahirnya UndangUndang No. 10 Tahun 2016 Tentang Perubahan Kedua Atas Undang-Undang Nomor 1 Tahun 2015 Tentang Penetapan Peraturan Pemerintah Pengganti Undang-Undang Nomor 1 Tahun 2014 Tentang Pemilihan Gubernur, Bupati, dan Walikota Menjadi Undang-Undang. Salah satu perubahan di dalam UU Nomor 8 Tahun 2015 dan Undang-Undang No.10 Tahun 2016 adalah adanya pembentukan Badan Peradilan Khusus sebagai lembaga yang akan menyelesaikan sengketa hasil Pilkada yang akan dibentuk paling lambat sebelum Pilkada serentak dilaksanakan (tahun 2027). 
Skema 1.

Dinamika Lembaga Penyelesai Sengketa Pilkada

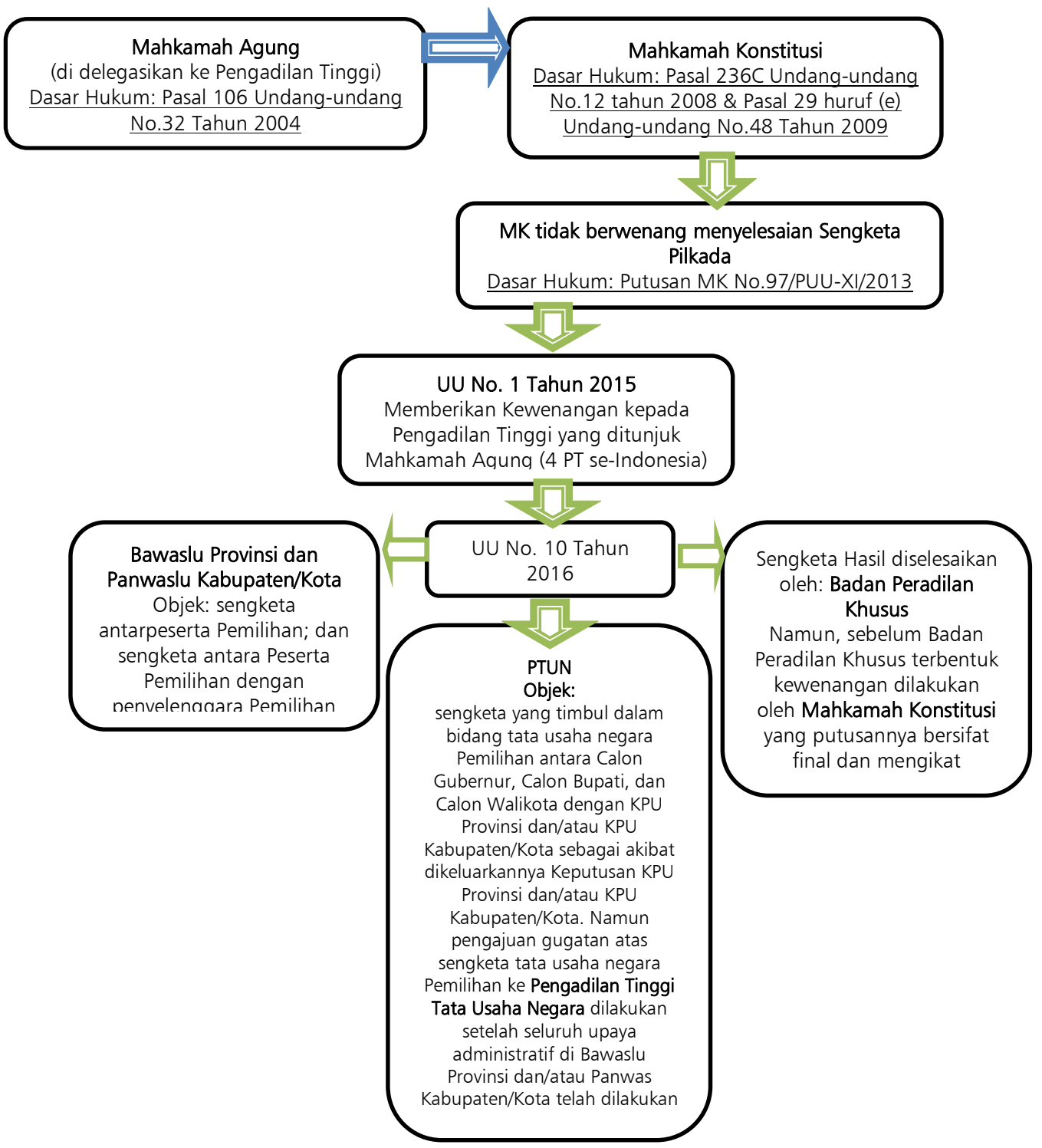

\section{B. Dinamika dan Problematika Politik}

\section{Hukum Lembaga Penyelesai Sengketa Pilkada}

Sengketa pilkada secara etimologis dapat dilihat dari istilah sengketa (dispute), sengketa tersebut merupakan implikasi dari timbulnya permasalahan-permasalahan yang timbul dalam pilkada, baik sengketa yang timbul pada saat proses penyelenggaraan, maupun sengketa terhadap hasil pilkada (suara sah yang ditetapkan KPUD). Hasil penelitian Institute for Democracy and Electoral Assistance (IDEA) (2010: 199) mendefinisikan electoral dispute yaitu "any complaint, chal- lenge, claim or contest relating to any stage of electoral process". Dari pengertian diatas, cakupan electoral dispute pada dasarnya memang luas dan meliputi semua tahapan pilkada yang memengaruhi kualitas dari pelaksanaan pilkada tersebut secara signifikan.

Permasalahan yang dipersengketakan dalam pilkada di Indonesia diantaranya meliputi (1) pelanggaran pidana dan administrasi pilkada; dan (2) perselisihan hasil perolehan suara. Menurut Topo Santoso bahwa apa yang disebut sengketa dalam penyelenggaraan pilkada sesungguhnya 


\section{MEDIA
HUKUM}

merupakan kasus pelanggaran administrasi atau kasus ketidakpuasan terhadap keputusan penyelenggara (Topo Santoso, 2011). Sukses pilkada tidak hanya diukur dari pelaksanaan pemungutan suara, melainkan juga ditentukan dari bagaimana penyelesaian sengketa yang mengiringinya. Persoalannya adalah terlalu banyak lembaga yang terlibat dalam penyelesaian sengketa pilkada yang tentu berdampak kurang baik terhadap proses penyelesaian sengketa pilkada (Anom Wahyu Asmorojati, 2015: 279). Disamping itu, kelembagaan penyelesaian sengketa hasil pilkada sering mengalami penggantian yang mengikuti alur politik hukum pilkada.

Penegakan hukum ini merupakan mekanisme untuk menjaga hak pilih rakyat. Tujuannya memastikan bahwa hak atas proses konversi suara yang adil dan tidak terlanggar dengan maraknya kecurangan dan tindakan manipulatif oleh peserta pemilu. Jauh lebih penting, bagaimana mekanisme hukum Pilkada mampu mengembalikan suara rakyat yang telah terkonversi kepada yang berhak sesuai dengan kehendak rakyat yang sesungguhnya. Perolehan suara dan keterpilihan calon tertentu, dapat dianulir oleh mekanisme hukum Pilkada, jika terbukti bahwa suara itu diperoleh dengan cara yang tidak dibenarkan menurut hukum (Veri Junaidi, 2009: 109)

Siklus perkembangan dinamika dan problematika lembaga penyelesaian sengketa hasil Pilkada dari awal hingga saat ini digambarkan seperti yang terlihat pada Skema 1.

\section{Mahkamah Agung}

a. Dasar Kewenangan

Pada awal penyelenggaraan pilkada, Undang-undang No.32 Tahun 2004 telah memberikan desain penyelesaian sengketa hasil pilkada. Berdasar pada Pasal 106 Undangundang tersebut, bahwa lembaga yang berwenang menyelesaikan sengketa pilkada adalah Mahkamah Agung (MA). Pasal 106 Undang-undang No.32 Tahun 2004 tentang Pemerintahan Daerah menyebutkan bahwa:

1) Keberatan terhadap penetapan hasil pemilihan kepala daerah dan wakil kepala daerah hanya dapat diajukan oleh pasangan calon kepada Mahkamah Agung dalam waktu paling lambat 3 (tiga) hari setelah penetapan hasil pemilihan kepala daerah dan wakil kepala daerah.

2) Keberatan sebagaimana dimaksud pada ayat (1) hanya berkenaan dengan hasil penghitungan suara yang mempengaruhi terpilihnya pasangan calon.

3) Pengajuan keberatan kepada Mahkamah Agung sebagaimana dimaksud pada ayat (1) disampaikan kepada pengadilan tinggi untuk pemilihan kepala daerah dan wakil kepala daerah provinsi dan kepada pengadilan negeri untuk pemilihan kepala daerah dan wakil kepala daerah kabupaten/kota.

4) Mahkamah Agung memutus sengketa hasil penghitungan suara sebagaimana dimaksud pada ayat (1) dan ayat (2) paling lambat 14 (empat belas) hari sejak diterimanya permohonan keberatan oleh Pengadilan Negeri/Pengadilan Tinggi/Mahkamah Agung.

5) Putusan Mahkamah Agung sebagaimana dimaksud pada ayat (4) bersifat final dan mengikat.

6) Mahkamah Agung dalam melaksanakan kewenangannya sebagaimana dimaksud pada ayat (1) dapat mendelegasikan kepada Pengadilan Tinggi untuk memutus sengketa hasil penghitungan suara pemilihan kepala daerah dan wakil kepala daerah kabupaten dan kota.

7) Putusan Pengadilan Tinggi sebagaimana dimaksud pada ayat (6) bersifat final.

\section{b. Problematika Kewenangan}

Kewenangan MA dalam penyelesaian sengketa hasil Pilkada kurang lebih berjalan 3 tahun (2005-2008), sebab dalam praktik memunculkan persoalan hukum. Misalnya permasalahan penyelesaian sengketa hasil Pilkada Depok oleh Pengadilan Tinggi Bandung yang mengemuka secara nasional. Dalam kasus ini, apabila menoleh pada pasal 106 ayat (7) Undang-undang No.32 Tahun 2004 tentang Pemerintah Daerah dan Peraturan Pemerintah No. 6 Tahun 2004, ditafsirkan putusan Pengadilan Tinggi bersifat final, sehingga mestinya tidak ada upaya hukum lagi yang dapat dilakukan. Namun frase, putusan Mahkamah Agung bersifat "final dan mengikat", sementara dalam UU tersebut putusan PT hanya bersifat "final", tanpa "mengikat". Tafsiran tersebut yang menginisiasi KPUD Depok mengajukan permohonan peninjauan kembali (PK) ke MA terhadap putusan Pengadilan Tinggi Bandung tersebut, pada akhirnya MA dalam putusan PK-nya mengabulkan permohonan Peninjauan Kembali dari KPUD Depok dan membatalkan putusan Pengadilan Tinggi 
Bandung. Perdebatan berpusar pada makna putusan yang bersifat final dan mengikat (final and binding) yang dalam penerapannya memunculkan ketidakpastian hukum, artinya problematika berkaitan dengan kepastian hukum dalam penyelesaian sengketa. Mahkamah Agung dengan kewenangan PK nya menganulir putusan Pengadilan Tinggi Bandung yang bersifat final dan mengikat (Tanto Lailam, 2015: 457).

Pada tahun 2008, Mahkamah Agung menyerahkan kewenangan penyelesaian sengketa pilkada kepada Mahkamah Konstitusi setelah adanya dasar hukum: Putusan MK No.072-073/PUU-II/2004, Undang-undang No.12 tahun 2008 Tentang Perubahan kedua atas Undang-undang No.32 tahun 2004 tentang Pemerintahan Daerah, Pasal 236C mengatur bahwa "Penanganan sengketa hasil penghitungan suara pemilihan kepala daerah dan wakil kepala daerah oleh MA dialihkan kepada MK paling lama 18 (delapan belas) bulan sejak Undang-undang ini diundangkan. Namun pada tahun 2014, kewenangan tersebut dinyatakan inkonstitusional oleh Putusan No.No.97/PUU-XI/2013.

Berdasar pada Undang-undang No.1 Tahun 2015 tentang Penetapan Peraturan Pemerintah Pengganti Undang-Undang Nomor 1 Tahun 2014 Tentang Pemilihan Gubernur, Bupati, dan Walikota Menjadi Undang-Undang, Pasal 157 ayat (1) mengatur bahwa: "Dalam hal terjadi perselisihan penetapan perolehan suara hasil Pemilihan, peserta Pemilihan dapat mengajukan permohonan pembatalan penetapan hasil penghitungan perolehan suara oleh KPU Provinsi dan KPU Kabupaten/ Kota kepada Pengadilan Tinggi yang ditunjuk oleh Mahkamah Agung", namun ayat (6) dan ayat (7) menyebutkan bahwa "Pihak yang tidak menerima Putusan Pengadilan Tinggi dapat mengajukan permohonan keberatan ke Mahkamah Agung dan putusan Mahkamah Agung bersifat final dan mengikat. Namun PT dan MA belum pernah melaksanakan ketentuan penyelesaian sengketa hasil pilkada menurut Undang-undang No.1 Tahun 2015 ini, sebab terjadi perubahan kelembagaan penyelesaian sengketa hasil berdasarkan Undang-undang No.8 Tahun 2015, dan terjadi lagi perubahan dengan lahirnya Undang-Undang No.10 Tahun 2016 Tentang Perubahan Kedua Atas Undang-Undang Nomor 1 Tahun 2015 Tentang Penetapan Peraturan Pemerintah Pengganti Undang-Undang Nomor 1 Tahun 2014 Tentang Pemilihan Gubernur, Bupati, dan Walikota Menjadi Undang-Undang.

\section{Mahkamah Konstitusi}

Kewenangan penyelesaian sengketa pilkada oleh MK ini bukan merupakan kewenangan original yang bersumber dari UUD 1945 (kewenangan tambahan), kewenangan ini merupakan jalan panjang proses penyelesaian sengketa yang sedang mencari bentuk. Diberikannya kewenangan ini kepada MK disebabkan adanya tafsir konstitusi yang memasukkan pilkada bagian dari rezim pemilu sebagaimana tertuang dalam Putusan MK No.072-073/PUU-II/2004, yang mana penyelesaian sengketa pemilu merupakan kewenangan original MK. Disisi lain, pada waktu itu MK merupakan lembaga yang sangat berwibawa - terpercaya dalam menyelesaikan sengketa-sengketa ketatanegaran (termasuk keberhasilan dalam penyelesaian sengketa pemilu). Namun, berjalannya waktu, penafsiran MK terkait penyelesaian sengketa pilkada dalam Putusan No.97/PUU-XI/2013 mengalami perubahan konstruksi, dalam putusan tersebut dinilai bahwa kewenangan MK adalah inkonstitusional dan berimplikasi pada pencabutan kewenangan MK dalam penyelesaian sengketa pilkada. Berikut dinamika dan problematika penyelesaian sengketa pilkada di MK:

a. Tafsir Konstitusi: Pilkada bagian Rezim Pemilu

Desain pilkada ini mengalami perubahan "makna" akibat adanya tafsir konstitusi bahwa pilkada dapat dikategorikan sebagai bagian dari pemilu, yang tentunya berimplikasi pada lembaga mana yang berwenang menyelesaikan sengketa hasil pilkada, menurut UUD 1945 bahwa MK merupakan lembaga negara yang menyelesaikan sengketa hasil pemilu. Putusan MK No.072-073/PUU-II/2004 memberikan pilihan hukum bagi pembentuk undang-undang untuk memasukan pilkada menjadi bagian rezim Pemilu atau pemerintahan daerah, maka pembentuk undang-undang kemudian memasukkan sengketa pilkada sebagai bagian dari sengketa Pemilu yang diselesaikan oleh MK. Dalam pertimbangannya disebutkan bahwa:

"Sebagai akibat (konsekuensi) logis dari pendapat Para Pemohon yang menyatakan bahwa Pilkada langsung adalah Pemilu sebagaimana dimaksud dalam Pasal $22 E$ UUD 1945 yang dijabarkan dalam UU Nomor 12 Tahun 2003, maka perselisihan mengenai hasil pemilu, menurut Para Pemohon, harus diputus oleh MK. Tentang permohonan Para Pemohon untuk menyatakan 
Pasal 106 ayat (1) sampai dengan ayat (7) sebagai bertentangan dengan UUD 1945, MK berpendapat bahwa secara konstitusional, pembuat undang-undang dapat saja memastikan bahwa Pilkada langsung itu merupakan perluasan pengertian Pemilu sebagaimana dimaksud dalam Pasal 22 E UUD 1945 sehingga karena itu, perselisihan mengenai hasilnya menjadi bagian dari kewenangan MK dengan ketentuan Pasal 24C ayat (1) UUD 1945. Namun pembentuk undang-undang juga dapat menentukan bahwa Pilkada langsung itu bukan Pemilu dalam arti formal yang disebut dalam Pasal $22 E$ UUD 1945 sehingga perselisihan hasilnya ditentukan sebagai tambahan kewenangan Mahkamah Agung sebagaimana dimungkinkan Pasal 24A ayat (1) UUD 1945 yang berbunyi, "Mahkamah Agung berwenang mengadili pada tingkat kasasi, menguji peraturan perundang-undangan di bawah undang-undang terhadap undang-undang, dan mempunyai wewenang lainnya yang diberikan oleh undang-undang".

Putusan MK tersebut ditindaklanjuti oleh pembentuk undang-undang dengan mengesahkan Undang-undang No.22 Tahun 2007 tentang Penyelenggaraan Pemilihan Umum, Pasal 1 angka 4) menyebutkan bahwa "Pemilu Kepala Daerah dan Wakil Kepala Daerah adalah Pemilu untuk memilih kepala daerah dan wakil kepala daerah secara langsung dalam NKRI berdasarkan Pancasila dan UUD 1945". Kemudian disahkan Undang-undang No.12 tahun 2008 Tentang Perubahan kedua atas Undang-undang No.32 tahun 2004 tentang Pemerintahan Daerah, Pasal 236C mengatur bahwa "Penanganan sengketa hasil penghitungan suara pemilihan kepala daerah dan wakil kepala daerah oleh MA dialihkan kepada MK paling lama 18 (delapan belas) bulan sejak Undang-undang ini diundangkan. Selain itu, disahkan pula Undang-undang No.48 Tahun 2009 tentang Kekuasaan Kehakiman, Pasal 29 huruf (e) yang mengatur ketentuan bahwa MK memiliki "kewenangan lain yang diberikan oleh undang-undang", yang dalam penjelasannya disebutkan bahwa" dalam ketentuan ini termasuk kewenangan memeriksa, dan memutus sengketa hasil pemilihan kepala daerah sesuai dengen ketentuan peraturan perundangundangan.
Menurut Hamdan Zoelva, bahwa perluasan kewenangan itu menandakan dua hal, yaitu: pertama, penegasan bahwa selain menjadi pengawal konstitusi (the guardian of the constitution), MK juga menjalankan fungsi sebagai pengawal demokrasi (the guardian of democracy). Dalam mengawal demokrasi, MK menjadi pemutus paling akhir atas sengketa hasil pilkada. Peran yang demikian membuat MK menyadari bahwa putusan tidak hanya menyangkut para kandidat yang sedang berkompetisi tetapi menentukan nasib rakyat dan demokrasi terutama di daerah di mana Pilkada digelar. Kedua, Pemilihan kepala daerah menjadi berada dalam lingkup pemilihan umum sebagaimana diatur dalam Pasal 22E UUD 1945 karena hanya sengketa pemilu-lah yang menjadi kewenangan MK. Dalam hal ini, MK harus dapat menunjukkan performa yang lebih baik dalam proses penanganannya. Artinya, agar pelaksanaan kewenangan ini dapat dijalankan secara optimal, MK harus memiliki dan mempersiapkan dukungan yang memadai dalam segala aspek (Hamdan Zoelva, 2013: 380-381). Dengan adanya pengalihan kewenangan sengketa Pilkada dari MA ke MK, harapan untuk menciptakan sistem berdemokrasi menjadi lebih baik, yang salah satu syarat berdemokrasi adalah adanya lembaga penyelesai sengketa yang bermartabat. Selain itu, bahwa peradilan MK lebih dekat secara kompetensi dibandingkan MA, sebab sengketa pemilu merupakan sengketa dibidang hukum tata negara, sehingga lebih tepat jika kewenangan tersebut diberikan kepada MK sebagai peradilan dibidang ketatanegaraan.

\section{b. Problematika Kewenangan Konstitusional}

Implikasi putusan MK No.072-073/PUU-II/2004 adalah kewenangan tambahan yang dimiliki oleh MK dalam penyelesaian sengketa Pilkada dan telah berjalan 6 tahun lamanya, artinya selama ini pilkada sebagai rezim pemilu tidaklah menimbulkan problem konstitusional dan keberadaan MK sebagai lembaga penyelesai sengketa hasil pilkada juga telah benar menurut konstitusi. Selama 6 tahun melaksanakan kewenangannya, MK menjadi lembaga yang berwibawa - terpercaya dalam penyelesaian sengketa hasil Pilkada, berbagai sengketa pun sukses diselesaikan. Bahkan pendekatan yang digunakan dalam penyelesaian sengketanya pun mengalami perubahan, yang lebih mendasarkan dan 
menggunakan pendekatan substantial justice yang mempersoalkan electoral process. MK secara tegas menjustifikasi bahwa dirinya mempunyai kewenangan untuk mempersoalkan judicial process untuk memastikan kualitas bukan sekedar kuantitas pemilu dengan menyatakan secara materiil telah terjadi pelanggaran ketentuan Pemilukada yang berpengaruh pada perolehan suara (Bambang Widjojanto, 2009: 6-7).

Pada titik itu, MK juga membuat kualifikasi, apakah pelanggaran itu bersifat sistematis, terstruktur dan masif meskipun hal ini menyebabkan putusan MK dinilai melebihi batas kewenangan yang dimilikinya sehingga terjadilah ultra vires dan ultra petita. Argumentasi tersebut secara tegas disebutkan, misal dalam Putusan No 41/PHPU.D-VI/2008 tentang Perselisihan Hasil Pemilukada Jawa Timur 2008 bahwa untuk mencapai demokrasi substansial maka MK tidak dapat dibelenggu oleh penafsiran sempit terhadap peraturan perundang-undangan. Pelanggaran yang bersifat sistematis, terstruktur dan masif dapat menjadi pertimbangan dalam memutus perselisihan hasil pilkada. Pelanggaran itu bersifat sistematis, artinya pelanggaran ini benar-benar direncanakan secara matang (by design), pelanggaran itu bersifat terstruktur artinya pelanggaran ini dilakukan oleh aparat struktural, baik aparat pemerintah maupun aparat penyelenggara pilkada secara kolektif bukan aksi individual, pelanggaran itu bersifat masif artinya dampak pelanggaran ini sangat luas dan bukan sporadis. Langkah MK tersebut merupakan terobosan hukum yang dilakukan untuk memajukan demokrasi dan melepaskan diri dari kebiasaan praktik pelanggaran sistematis, terstruktur dan masif. MK tidak hanya melakukan penghitungan kembali hasil penghitungan suara tetapi juga harus menggali keadilan dengan menilai dan mengadili hasil penghitungan yang diperselisihkan (M. Mahrus Ali, dkk., 2011: 3-4).

Problem kewenangan MK ini mulai terguncang dengan muncul kegaduhan politik salah satu Hakim Konstitusi yang terjaring "operasi tangkap tangan dalam penyelesaian sengketa pilkada". Kemudian dikeluarkan Peraturan Pemerintah Pengganti Undang-Undang No.1 Tahun 2013 tentang Perubahan Kedua Atas Undang-Undang No.24 Tahun 2003 (disahkan menjadi UU No.4/2014). Menurut Ni'matul Huda, Perppu MK layak untuk diapresiasi, karena Perppu MK dikeluarkan oleh Pemerintah dimaksudkan untuk mengembalikan kepercayaan publik terhadap MK akibat adanya kemerosotan integritas dan kepribadian salah satu hakim konstitusi. MK dibangun dari gagasan besar dan mimpi rakyat Indonesia untuk memiliki rumah keadilan masa depan yang kokoh. Namun apa boleh dikata, skandal suap yang melibatkan mantan Hakim konstitusi ini langsung menghancurkan kredibilitas dan legitimasi putusan-putusan yang telah dikeluarkan MK selama ini. Kepercayaan publik runtuh seketika, pencitraan bahwa MK merupakan salah satu lembaga negara yang dianggap steril dari praktik korupsi pun memudar. Citra yang buruk MK saat ini tampaknya juga menghapus fakta bahwa MK pernah berprestasi dalam memutus sengketa pilkada (Tanto Lailam, 2015: 378)

Tidak berlangsung lama, desain pilkada kembali mengalami perubahan setelah adanya Putusan No.97/PUU-XI/2013 yang menyatakan bahwa MK tidak berwenang lagi menyelesaikan sengketa Pilkada, dalam putusan tersebut MK menyatakan bahwa "penambahan kewenangan Mahkamah Konstitusi untuk mengadili perkara perselisihan hasil pemilihan kepala daerah dengan meperluas makna pemilihan umum yang diatur Pasal 22E UUD 1945 adalah inkonstitusional". Kewenangan penyelesaian sengketa Pilkada diamputasi karena berdasarkan penafsiran orginal intent bahwa MK hanya menyelesaikan sengketa Pemilu saja (sengketa Pemilu DPR, DPD, DPRD dan Presiden), jadi tidak menyelesaikan sengketa Pilkada. Putusan ini menganulir putusan No.072-073/PUU-II/2004, dan inti dari putusan MK No.97/PUUXI/2013 mengembalikan desain penyelesaian sengketa Pilkada kepada Pembentuk Undang-undang.

Artinya pilkada tidak lagi dapat dikategorikan sebagai bagian dari pemilihan umum menurut Pasal 22E UUD 1945. Dalam Putusan MK tersebut dinyatakan bahwa beberapa landasan hukum (Pasal) kewenangan MK dalam penyelesaian sengketa Pilkada bertentangan dengan UUD 1945 dan tidak mempunyai kekuatan hukum mengikat, yaitu: Pasal $236 \mathrm{C}$ Undang-undang No.12 tahun 2008 Tentang Perubahan kedua atas Undang-undang No.32 tahun 2004 tentang Pemerintahan Daerah "Penanganan sengketa hasil penghitungan suara pemilihan kepala daerah dan wakil kepala daerah oleh MA dialihkan kepada MK paling lama 18 (delapan belas) bulan sejak Undang-undang ini diundangkan. Selain itu, 


\section{MEDIA
HUKUM}

Pasal 29 huruf (e) Undang-undang No.48 Tahun 2009 tentang Kekuasaan Kehakiman yang mengatur ketentuan bahwa MK memiliki "kewenangan lain yang diberikan oleh undang-undang"(sengketa Pilkada). Namun, MK tetap memiliki kewenangan mengadili perselisihan Pilkada selama belum ada undang-undang yang mengatur mengenai hal tersebut.

Argumentasi hukum yang dibangun MK bahwa untuk memahami kewenangan MK yang ditentukan dalam Pasal 24C ayat (1) UUD 1945 harus melihat kembali makna teks dan original intent. Original intent tersebut digunakan untuk mengkaji kewenangan MK dan makna Pemilu berdasarkan UUD 1945. Menurut MK bahwa mengingat ketentuan mengenai lembaga negara yang ditentukan oleh UUD 1945 dan kewenangannya masing-masing harus secara rigid mengikuti norma konstitusi, sebagaimana Putusan MK No.12/PUU-XII/2014 Pengujian Undang-undang No.4 Tahun 2014 tentang Penetapan Peraturan Pemerintah Pengganti UndangUndang No.1 Tahun 2013 tentang Perubahan Kedua Atas Undang-Undang No.24 Tahun 2003 tentang Mahkamah Konstitusi Menjadi Undang-undang, yang menyebutkan bahwa:

"Selain itu, dalam rangka menjaga sistem ketatanegaraan yang menyangkut hubungan antar lembaga negara yang diatur oleh UUD 1945 sebagaihukum tertinggi, MK harus menggunakan pendekatan yang rigid sejauh UUD 1945 telah mengatur secara jelas kewenangan atributif masing-masing lembaga tersebut. Dalam hal MK terpaksa harus melakukan penafsiran atas ketentuan yang mengatur sebuah lembaga negara maka MK harus menerapkan penafsiran original intent, tekstual, dan gramatikal yang komprehensif yang tidak boleh menyimpang dari apa yang telah secara jelas tersurat dalam UUD 1945 termasuk juga ketentuan tentang kewenangan lembaga negara yang ditetapkan oleh UUD 1945. Apabila MK tidak membatasi dirinya dengan penafsiran secara rigid tetapi melakukan penafsiran secara sangat bebas terhadap ketentuan yang mengatur lembaga negara dalam UUD 1945, sama artinya MK telah membiarkan pembentuk undangundang untuk mengambil peran pembentuk UUD 1945 dan akan menjadi sangat rawan terjadi penyalahgunaan kekuasaan manakala Presiden didukung oleh kekuatan mayoritas DPR, atau bahkan MK sendiri yang mengambil alih fungsi pembentuk UUD 1945 untuk mengubah UUD 1945 melalui putusan-putusannya.

Intinya bahwa Putusan MK No.072-073/PUU-II/2004 yang berimplikasi pada penambahan kewenangan konstitusional MK dalam penyelesaian sengketa Pilkada, dan Putusan MK No.97/PUU-XI/2013 yang berimplikasi pada pencabutan kewenangan konstitusional MK dalam penyelesaian sengketa pilkada. Terlihat dalam putusan tersebut bahwa desain penyelesaian sengketa Pilkada di Indonesia sering mengalami perubahan akibat tafsir konstitusional yang tidak konsisten, jadi perubahan bukan karena kehendak pembentuk undang-undang dalam proses legislasi.

Penulis melihat bahwa ketidakkonsistenan kelembagaan MK dalam membuat putusan dalam kasus lembaga penyelesai sengketa pilkada diakibatkan oleh makna ganda konstitusi, maksudnya adalah adanya perbedaan pemahaman konstitusi dan penggunaan metode penafsiran dalam memahami norma hukum (Pasal) UUD 1945. UUD 1945 dilihat tidak hanya yang tertulis, tetapi juga spirit dan jiwa yang ada di dalamnya, makna UUD 1945 harus disadari tidak hanya teks, tetapi juga keberlakukan dari teks tersebut yang mampu memberikan solusi terhadap permasalahan bangsa dan negara. Tugas MK tidak hanya berhenti pada teks (penafsiran original intent), tetapi lebih jauh dari itu, yaitu mampu menghidupkan konstitusi ditengah perubahan zaman dan problema bangsa dan negara. Penafsiran UUD 1945 harus mampu menjadi jalan hidup dan menghidupi setiap nafas bangsa dan negara, sehingga agar nafas bangsa dan negara tidak terhenti, maka makna teks saja tidak cukup, tetapi membutuhkan makna yang sesungguhnya "makna hukum yang hidup dalam masyarakat (the living constitutions)".

Putusan No.072-073/PUU-II/2004 adalah putusan yang mampu menterjemahkan teks Pasal 22E dan Pasal 18 ayat (4)UUD 1945 kedalam permasalahan yang dihadapi bangsa ini, memberikan solusi, sekaligus menawarkan desain yang baik dalam penyelesaian sengketa pilkada (non original intent). Sementara Putusan MK No.97/PUU-XI/2013 adalah putusan yang mengedepankan makna konstitusi berdasarkan 
apa yang tertulis dalam teks norma hukum dan mengutamakan penggunaan penafsiran original intent. Memang jika ditelaah berdasarkan kebenaran konstitusi, pemaknaaan atas konstitusi dan penggunaan metode penafsiran dalam dua putusan tersebut dapat dibenarkan secara teori maupun praktik pengujian undang-undang. Namun, dalam ranah praktik demokrasi, putusan tersebut menyebabkan politik hukum lembaga penyelesai sengketa pilkada kehilangan arah, berubah-ubah dan tidak memiliki pegangan yang pasti.

\section{Gagasan Badan Peradilan Khusus}

Setelah putusan MK No.97/PUU-XI/2013 yang berimplikasi pada pencabutan kewenangan konstitusional MK dalam penyelesaian sengketa Pilkada, Presiden mengeluarkan Perpu Nomor 1 Tahun 2014, yang menentukan bahwa perselisihan hasil pilkada diselesaikan oleh MA. Perpu tersebut disetujui oleh DPR menjadi UU No. 1 Tahun 2015. Namun, belum sempat UU tersebut dilaksanakan, UU No.1 Tahun 2015 tersebut diubah dengan disahkannya UU No 8 Tahun 2015. Berdasarkan UU No 8 Tahun 2015 dan berganti lagi dengan UU No.10 Tahun 2016, proses penyelesaian sengketa pilkada terbagai ke dalam dua bentuk: (1) proses penyelesaian sengketa yang berkaitan dengan penyelenggaraan pilkada diselesaikan oleh Bawaslu/ Panwaslu dan Pengadilan Tinggi Tata Usaha Negara (PTTUN); dan (2) Pasal 157 UU tersebut mengatur bahwa perkara perselisihan hasil pemilihan diperiksa dan diadili oleh badan peradilan khusus. Pasal 157 juga mengatur sebelum badan peradilan khusus tersebut terbentuk (sebelum pelaksanaan pilkada serentak), kewenangan penyelesaian sengketa pilkada menjadi kewenangan Mahkamah Konstitusi.

Politik hukum pembentukan badan peradilan khusus yang menangani sengketa pilkada ini masih bias dan membutuhkan kajian komprehensif, sebab jangan sampai badan peradilan khusus yang akan dibentuk justru akan menjadi malapetaka demokrasi lokal. Badan peradilan khusus harus memiliki desain ideal dan menjadi tolok ukur demokrasi lokal, selain itu desain badan peradilan khusus ini harus lebih ideal dibandingkan lembaga-lembaga penyelesai sengketa sebelumnya. Persoalannya, tidak dijumpai kejelasan mengenai seperti apa seharusnya badan peradilan khusus tersebut, tidak memberikan ketentuan yang detail mengenai kedudukan (struktur) dan kewenangan badan peradilan khusus tersebut, apakah desain kelembagaannya akan diletakkan di salah satu badan peradilan di bawah Mahkamah Agung atau dibentuk lembaga lain diluar lingkungan peradilan tersebut. Selain itu, tidak jelas pula apakah kedudukannya di tingkat pusat, provinsi atau kabupaten/ kota.

Jika merujuk pada Undang-Undang Nomor 48 Tahun 2009 tentang Kekuasaan Kehakiman yang memberikan kewenangan kepada pembentuk undang-undang untuk membentuk badan peradilan khusus. Pasal 1 angka 8 Undang-Undang Nomor 48 Tahun 2009 menentukan bahwa "Pengadilan Khusus adalah pengadilan yang mempunyai kewenangan untuk memeriksa, mengadili dan memutus perkara tertentu yang hanya dapat dibentuk dalam salah satu lingkungan badan peradilan yang berada di bawah Mahkamah Agung yang diatur dalam undang-undang". Lebih lanjut Pasal 27 ayat (1) Undang-Undang Nomor 48 Tahun 2009 menentukan bahwa "Pengadilan khusus hanya dapat dibentuk dalam salah satu lingkungan peradilan yang berada di bawah Mahkamah Agung sebagaimana dimaksud dalam Pasal 25".

Permasalahannya, jika badan peradilan khusus tersebut diletakkan dalam lingkup peradilan dibawah Mahkamah Agung sebagaimana diamanatkan Undang-Undang Nomor 48 Tahun 2009, di lingkup peradilan manakah (apakah peradilan umum atau peradilan tata usaha negara. Berikut batasan kewenangan dua peradilan tersebut sebagaimana tertuang dalam Pasal 25 Undang-Undang Nomor 48 Tahun 2009:

Ayat (1): Badan peradilan yang berada di bawah Mahkamah Agung meliputi badan peradilan dalam lingkungan peradilan umum, peradilan agama, peradilan militer, dan peradilan tata usaha negara.

Ayat (2): Peradilan umum sebagaimana dimaksud pada ayat (1) berwenang memeriksa, mengadili, dan memutus perkara pidana dan perdata sesuai dengan ketentuan peraturan perundang-undangan

Ayat (5): Peradilan tata usaha negara sebagaimana dimaksud pada ayat (1) berwenang memeriksa, mengadili, memutus, dan menyelesaikan sengketa tata usaha negara sesuai dengan ketentuan peraturan perundang-undangan.

Dengan struktur peradilan yang ada, kita dapat mengkon- 


\section{MEDIA
HUKUM}

solidasikan semua ide tentang lembaga peradilan yang bersifat khusus secara pasti ke dalam salah satu lingkungan peradilan yang ditentukan oleh UUD 1945 itu. Semua bentuk dan jenis pengadilan khusus harus dikembalikan hakikat keberadaannya dalam konteks lingkungan peradilan umum, peradilan agama, peradilan tata usaha negara, atau peradilan militer (Jimly Asshiddiqie, 2016). Menurut Dian Agung Wicaksono (2015:177) bahwa desain badan peradilan khusus pilkada yang sesuai adalah bersifat ad hoc dan berada di lingkungan Mahkamah Agung, peradilan ini memiliki kewenangan untuk menangani segala hal yang berkaitan dengan sengketa pilkada, baik sengketa proses penyelenggaraan, sengketa hasil, maupun permasalahan administrasi maupun pidana, sedangkan untuk pelanggaran kode etik tetap menjadi kewenangan Dewan Kehoramatan Penyelenggara Pemilihan Umum.

Yang paling memungkinkan, jika badan peradilan khusus dibentuk dalam lingkup peradilan di bawah Mahkamah Agung adalah badan peradilan tata usaha negara. Hal ini mengingat bahwa penyelesaian sengketa penyelengaraan pilkada juga menjadi kewenangan lingkup badan peradilan tata usaha negara, maka sengketa hasilpun idealnya juga menjadi kewenangannya. Hal ini tentu lebih integratif dengan menyatukan kewenangan sengketa pilkada mulai sengketa administratif, sengketa penyelenggaraan dan sengketa hasil (sengketa hasil ini disebabkan adanya keputusan tata usaha negara/ keputusan KPUD). Mengingat kewenangan dalam penyelesaian sengketa administratif dan sengketa penyelenggaraan menjadi kewenangan PT TUN (banding administratif), maka badan peradilan khusus pilkada secara kelembagaan dapat dimasukkan ke-dalam bagian PT TUN.

\section{SIMPULAN}

Dinamika dan problematika lembaga penyelesai sengketa pilkada mengalami pasang surut, diawali dari kewenangan MA (dilaksanakan oleh PT) yang dalam praktiknya menimbulkan ketidakpastian hukum dalam penyelesaian sengketanya. Putusan Pengadilan Tinggi Bandung yang bersifat final dan mengikat mampu dianulir oleh putusan PK Mahkamah Agung. MA menjalankan kewenangannya selama 3 tahun dan pada tahun 2008 kewenangan penyelesaian sengketa menjadi kewenangan MK berdasarkan tafsir konstitusi dalam Putusan MK No.072-073/PUU-1I/2004 yang memasukkan pilkada sebagai bagian dari rezim pemilu, kemudian putusan tersebut ditindaklanjuti dengan Undang-undang No.12 tahun 2008 Tentang Perubahan kedua atas Undang-undang No.32 tahun 2004 tentang Pemerintahan Daerah, Pasal 236C mengatur bahwa "Penanganan sengketa hasil penghitungan suara pemilihan kepala daerah dan wakil kepala daerah oleh MA dialihkan kepada MK paling lama 18 (delapan belas) bulan sejak Undang-undang ini diundangkan".

Setelah berlangsung selama 6 tahun, desain lembaga penyelesai sengketa hasil pilkada kembali tergunjang setelah adanya Putusan No.97/PUU-XI/2013 yang menyatakan bahwa MK tidak berwenang lagi menyelesaikan sengketa Pilkada, bahwa "penambahan kewenangan Mahkamah Konstitusi untuk mengadili perkara perselisihan hasil pemilihan kepala daerah dengan meperluas makna pemilihan umum yang diatur Pasal 22E UUD 1945 adalah inkonstitusional". Dalam putusan MK tersebut dan UU No.8 Tahun 2015 di inisiasi gagasan pembentukan badan peradilan khusus yang menyelesaikan sengketa pilkada. Namun melihat desain badan peradilan khusus yang sesuai dengan UUD 1945 dan peraturan di bawahnya bahwa yang paling memungkinkan dibentuk dalam badan peradilan tata usaha negara. Hal ini mengingat bahwa penyelesaian sengketa penyelengaraan pilkada juga menjadi kewenangan lingkup badan peradilan tata usaha negara, maka sengketa hasilpun idealnya juga menjadi kewenangannya.

\section{DAFTAR PUSTAKA}

\section{Buku}

Fajar, Mukti, dan Yulianto Achmad, Dualisme Penelitian Hukum Normatif dan Empiris, Yogyakarta, Pustaka Pelajar

Ibrahim, Johnny, 2005, Teori $\mathcal{E}$ Metodologi Penelitian Hukum Normatif, Bayumedia Publising, Surabaya Refly Harun, 2016, Pemilu Konstitusional: Desain Penyelesaian Sengketa Pemilu Kini dan ke Depan, Jakarta, PT Raja Grafindo Persada

Lailam, Tanto, 2015, Pertentangan Norma Hukum: dalam Teori dan Praktik Pengujian Undang-undang di Indonesia, Yogyakarta, LP3M UMY 
M.Gaffar, Janedjri, 2012, Politik Hukum Pemilu, Jakarta, Konstitusi Press (Konpress)

Pamungkas, Sigit, 2012, Pemilu, Perilaku Pemilih dan Kepartaian, Yogyakarta, Institute for Democracy and Welfarism

Widjojanto, Bambang, 2009, Kajian Putusan MK Tentang Pemilu $\mathcal{E}$ Pemilukada, Jakarta, Kemitraan

\section{Artikel}

Ali, M. Mahrus, dkk., 2011, Tafsir Konstitusional Pelanggaran Pemilukada yang Bersifat Sistematis, Tersktruktur dan Massif, MKRI, Jakarta

Arifin Hoesein, Zainal, dalam "Pemilu Kepala Daerah dalam Transisi Demokrasi”, Jurnal Konstitusi, Volume 7, Nomor 6, Desember 2010

Asmorojati, Anom Wahyu, Proceeding Seminar Nasional "Mewujudkan Kedaulatan Rakyat melalui Pemilu dan Pilkada Serentak yang Berkualitas dan Akuntabel”, PK2P, FH UMY, 17 Oktober 2015

Asshiddiqie, Jimly, "Pengadilan Khusus", diunduh dari http://www.jimly.com/makalah/namafile/126 / PENGADILAN_KHUSUS_02.pdf, pada tanggal 25 Mei 2016

Bisariyadi, dkk., dalam "Komparasi Mekanisme Penyelesaian Sengketa Pemilu di Beberapa Negara Penganut Paham Demokrasi Konstitusional, Jurnal Konstitusi Volume 9, Nomor 3, September 2012

IDEA International, Electoral Justice: The International IDEA Handbook, (Stockholm: Bulls Graphics, 2010)

Junaidi, Veri, dalam "Menata Sistem Penegakan Hukum Pemilu Demokratis Tinjauan Kewenangan MK atas Penyelesaian Perselisihan Hasil Pemilu”, Jurnal Konstitusi, Volume 6, Nomor 3, September 2009

Prasetyoningsih, Nanik, dalam "Dampak Pemilihan Umum Serentak bagi Pembangunan Demokrasi di Indonesia", Jurnal Media Hukum Volume 21 No.2 Desember 2014

Santoso, Topo, makalah berjudul "Perselisihan Hasil Pemilukada" disampaikan pada acara Diskusi Terbatas di Mahkamah Konstitusi pada tanggal 24 Maret 2011 di Jakarta.

Wicaksono, Dian Agung, dan Ola Anisa Ayutama, "Inisiasi Pengadilan Khusus Pemilihan Kepala Daerah dalam menghadapi Keserentakan Pemilihan Gubernur, Bupati dan Walikota di Indonesia”, Jurnal
Rechts Vinding, Volume 4 No.1, April 2015

Zoelva, Hamdan, "Problematika Penyelesaian Sengketa Hasil Pemilukada oleh Mahkamah Konstitusi”, Jurnal Konstitusi, Volume 10, 3 September 2013

Zuhro, Siti, dalam "Memahami Demokrasi Lokal: Pilkada, Tantangan, dan Prospeknya”, Jurnal Pemilu dan Demokrasi Volume 4 Desember 2012 